\title{
An Unusual Presentation of Plasma Cells - Castleman Disease: A Case Report
}

\author{
MARIANA MIHĂILĂ ${ }^{1}, \mathrm{~V}$. HERLEA ${ }^{2}$, CAMELIA DOBREA $^{3}$, IOANA LUPESCU ${ }^{4}$, GINA RUSU MUNTEANU $^{4}$, \\ GRETHI CHIRIAC ${ }^{1}$, L. MICU, R. SERESCU ${ }^{1}$, I. COPACI ${ }^{1}$ \\ ${ }^{1}$ Department of Internal Medicine, Fundeni Clinical Institute, Bucharest, Romania \\ ${ }^{2}$ Department of Pathology, Fundeni Clinical Institute, Bucharest, Romania \\ ${ }^{3}$ Center of Hematology, Fundeni Clinical Institute, Bucharest, Romania \\ ${ }^{4}$ Department of Radiology - Fundeni Clinical Institute, Bucharest, Romania
}

\begin{abstract}
We present the case of a 76 year old female patient admitted in the Department of Cardiology for physical asthenia, profuse sweating and dyspnea with orthopnea for about one month. Clinical and paraclinical assessments performed at admission confirmed the diagnosis of cardiac tamponade. Surgical intervention was performed and $400 \mathrm{~mL}$ of clear effusion were drained. Post-operative evolution was marked by recurrence of symptoms, requiring after 3 weeks a new drainage of $600 \mathrm{~mL}$ of clear effusion, and biopsy of the pericardium was performed. Pathological exam described serous pericarditis with chronic inflammatory infiltrate, xanthogranulomatous reaction intricated in the pericardium and mesothelial hyperplasia. The patient was subsequently transferred to the Department of Internal Medicine for further investigations. Physical examination showed a patient with altered general status, pallor, vesicular murmur absent in both bases, presenting cutaneous hyperpigmentation at the level of the right hemi-abdomen and hip with posterior extension, and a peripheral indurated erythematous plaque. The patient presented nodular masses of $3 \mathrm{~cm}$ in the right latero-cervical and bilateral axillary regions, non-adherent to the superficial structures, as well as adenopathic blocks in both inguinal regions. CT scan of the thorax and abdomen showed moderate bilateral pleuresia, minimal pericardial effusion $(15 \mathrm{~mm})$ and multiple adenopathies on both sides of the diaphragm. Skin biopsy was performed, as well as bone marrow aspirate and excision of a right axillary lymph node. Pathological exams and immunohistochemistry tests confirmed the diagnosis of Plasma Cells Castleman disease.
\end{abstract}

Key words: Castleman disease, plasma cells, pericardial tamponade, lymph nodes, organomegaly.

\section{INTRODUCTION}

Castleman disease is a disease of the lymph nodes and of related tissues. Castleman disease is also known as giant lymph node hyperplasia and angiofollicular lymph node hyperplasia [1]. Evaluation of a reactive lymph node is essential for diagnosis and to exclude malignancy and other atypical lymph node hyperplasia. Interpretation of histopathology in Castleman disease should be performed in correlation with clinical manifestations and tests for proinflammatory cytokines (IL6), for HIV, human herpes virus 8 (HHV8), Epstein Barr virus and cytomegalovirus.

Keller, Hochholzer and Castleman distinguished two variants of Castleman disease: hyaline-vascular (HV) and plasma-cell (PC) [2]. HV-variant Castleman disease presents typical histological features: lymphoid proliferation, regression of follicles and expanded mantle zones with small lymphocytes arranged in an "onion-skin" fashion. The interfollicular zone is expanded with prominent hyalinized blood vessels, dendritic cells and small T-lymphocytes. Plasma cells and eosinophils are not abundant. The vascular proliferation in HV-Castleman disease is determined by increased vascular endothelial growth factor (VEGF) expression [3]. Deficiency of BCL-6 positive germinal center cells and follicular T cells (BCL-6 positive, CD 57 positive) had been demonstrated by immunohistochemistry [4].

The follicular mantle cells in HV-Castleman disease express CD5 and CD20 [5]. The lymphocytes are polyclonal, as shown by molecular analysis [6]. The proliferations of follicular dendritic cells (FDC) may generate a wide range of anomalies, from stromal rich variants to neoplasms [7]. FDCs in Castleman disease present strong expression of epidermal growth factor receptor (EGFR) [8].

\section{CASE REPORT}

A 76 year old female patient was admitted in the Department of Internal Medicine - Fundeni Clinical Institute for investigations, after two episodes of cardiac tamponade of unknown etiology in the 
previuos month. The symptoms had started for one month with fatigue, dyspnea, weight loss and profuse sweating. Echocardiography exam at that time confirmed the diagnosis of cardiac tamponade, and surgical intervention was performed with drainage of $400 \mathrm{~mL}$ of clear effusion. The symptoms reappeared soon after drainage, requiring after three weeks surgical reintervention with drainage of $600 \mathrm{~mL}$ of clear effusion, and biopsy of the pericardium was performed. Pathological exam described serous pericarditis with chronic inflammatory infiltrate, xanthogranulomatous reaction intricated in the pericardium and mesothelial hyperplasia. The patient was referred to our department for evaluation. The patient complained of weight loss of five kilograms over the past month and a progressive cutaneous pigmentation over the last ten years. At admission, the axillary temperature was 36.8 Celsius degrees. The patient was noted to be conscious, alert and oriented but with altered general status. Physical examination was significant for pallor and sweaty skin, associated with cutaneous hyperpigmentation at the level of the right hemi-abdomen and hip with posterior extension, and a peripheral indurated erythematous plaque (Figure 1).

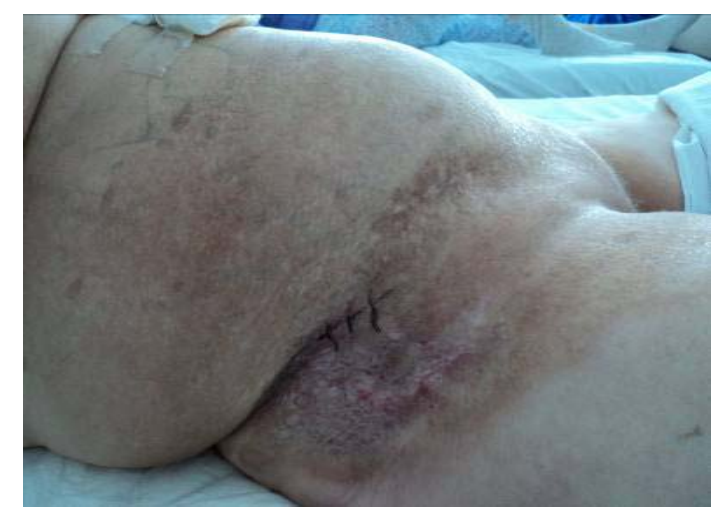

Figure 1. Cutaneous hyperpigmentation at the level of the right hemi-abdomen and hip with posterior extension, and a peripheral indurated erythematous plaque.

Right laterocervical, bilateral axillary and bilateral inguinal lymph nodes were detected, measuring $3 / 3$ centimeters $(\mathrm{cm})$; these adenomegalies were non-adherent to the superficial structures. Hepatomegaly and moderate splenomegaly were also remarked. Initial laboratory testing included a complete blood count with differential, chemistry and coagulation panels, urinalysis, and computerized tomography (CT) scans of the thorax, abdomen and pelvis. Blood tests were unremarkable excepting leukocytosis of $11210 / \mathrm{mmc}$ and moderate anemia with hemoglobin levels of $8 \mathrm{~g} / \mathrm{dL}$. HIV test was negative. The CT scan revealed widespread lymphadenopathies involving the neck, axillae, chest/mediastinum, abdomen and pelvis. CT also showed moderate bilateral pleuresia and minimal pericardial effusion (Figure 2).

Biopsy of the skin lesion was obtained from the right hip. A mild infiltrate of lymphocytes and plasma cells located around the vessels in the superficial dermis and collagen fibrosis in the deep dermis were noted (Figure 3).
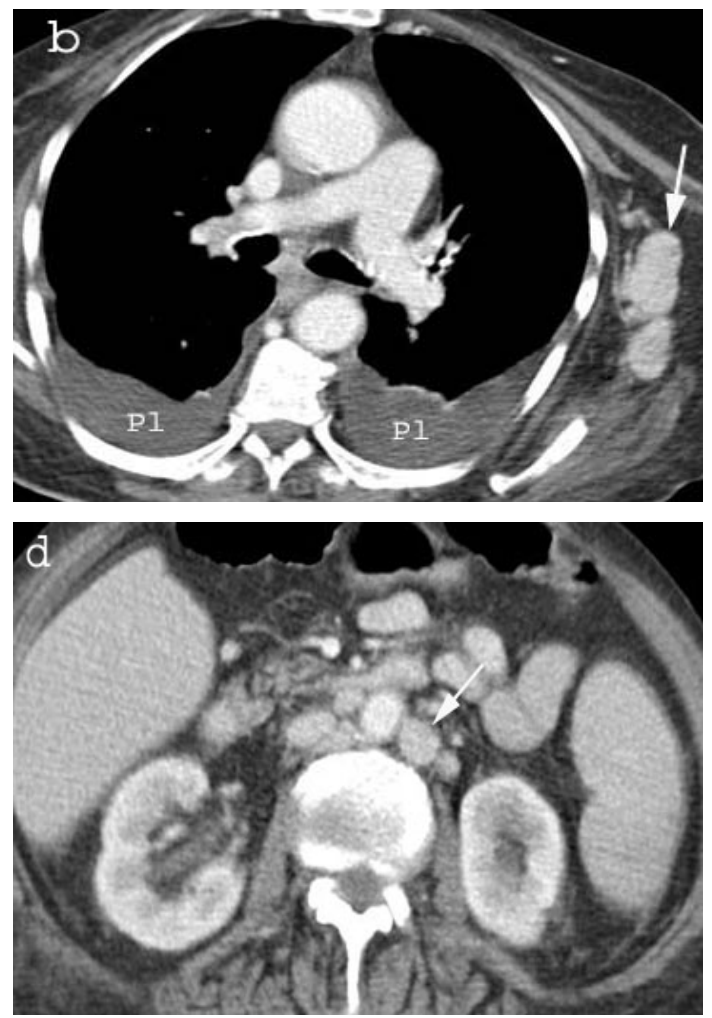

Figure 2. Contrast enhanced CT evaluation of the thorax (b) and abdomen (d): huge bilateral axilar adenopathies with important enhancement (arrows); small mediastinal lymphadenopathies (arrowhead); bilateral pleural fluid collection (Pl); multiple abdominal adenopathies (arrows).

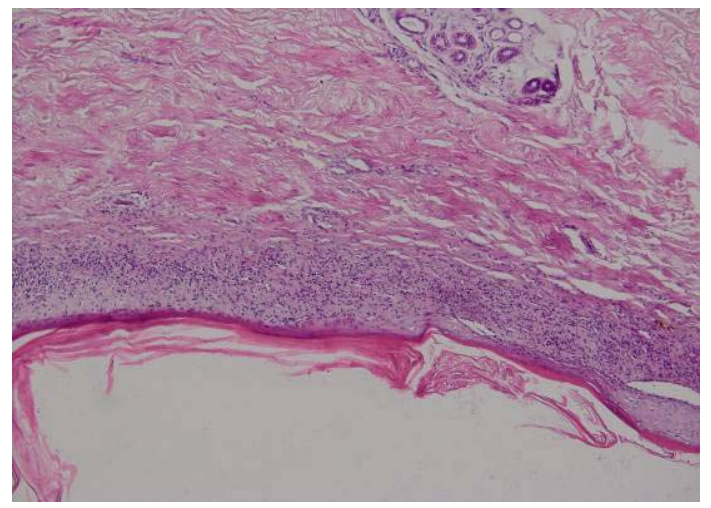

Figure 3. Skin biopsy: infiltration of mature plasma cells and lymphocytes in linear pattern in the dermis; hematoxylin and eosin (Magnification $\times 100$ ). 
Open biopsy of the right axillary lymph node was performed by the surgical service. The specimens from these biopsies were sent to pathology for histologic review, which revealed increased plasma cells infiltrate (Figure 4). The immunochemistry tests performed on the skin and lymph node biopsies showed plasma cells infiltrates with kappa and lambda light chain with a kappa/lambda $(\mathrm{K} / \mathrm{L})$ ratio of $4 / 1$ (poly-clonal). The final pathology report concluded that the skin and lymph node lesions consisted in polyclonal lymphoid proliferation that was compatible with the plasma cell variant of Castleman disease. We also performed bone marrow aspirate. The marrow was hypercellular with very rich plasma cells infiltrates (20-25\%) (Figure 5).

We initiated corticosteroid therapy consisting in dexamethasone, $16 \mathrm{mg}$ daily. Initially we obtained a transient improvement of symptoms. Unfortunately after three weeks of treatment the general condition of the patient deteriorated, with high intensity abdominal pains. The repeated complete blood count revealed $68.670 / \mathrm{mm}^{3}$ white blood cells with an absolute neutrophil count of $60160 / \mathrm{mm}^{3}$ and anemia (hemoglobin $8 \mathrm{~g} / \mathrm{dL}$ ). The patient presented cardiac arrest and died.

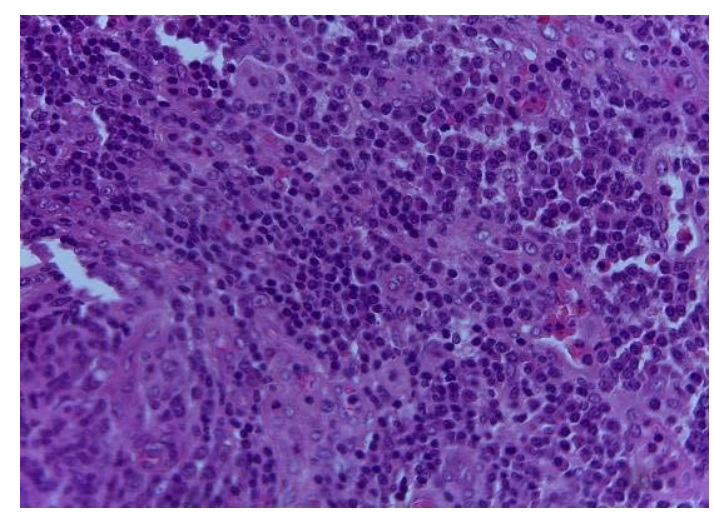

Figure 4. Lymph node biopsy - parafollicular plasma cell infiltration, hematoxylin and eosin (Magnification $\times 40$ ).

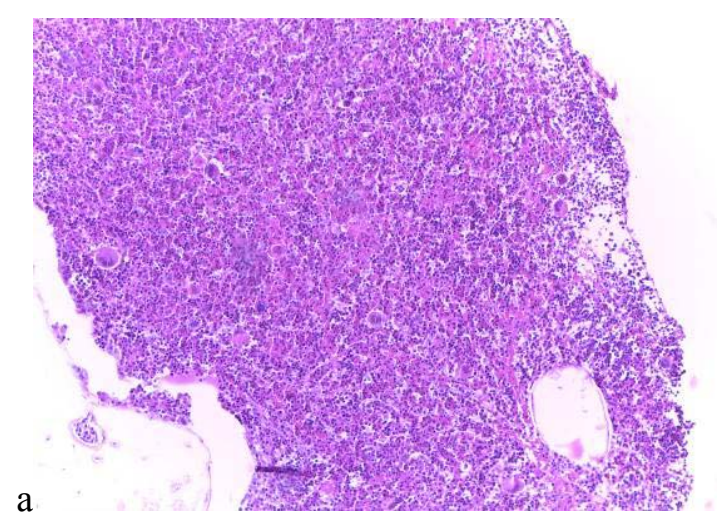

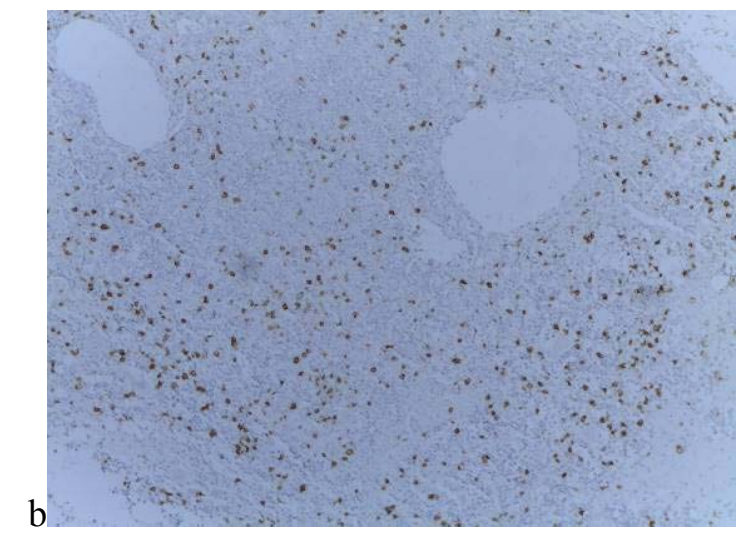

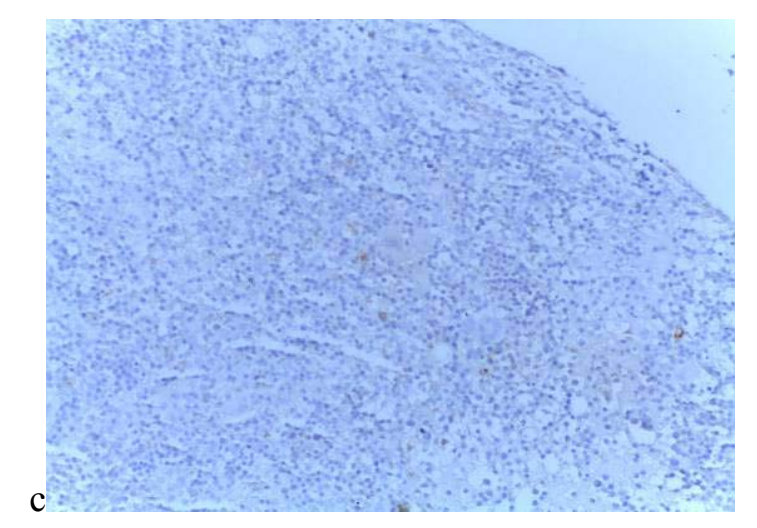

Figure 5. Bone marrow biopsy. 3a- Hypercellular bone marrow, hematoxylin and eosin, Magnification $\times 10$. 3b- CD20-positive small lymphocytes, immunohistochemistry, Magnification $\times 10$. 3c- CD34-positive lymphocytes, immunohistochemistry, Magnification $\times 20$.

\section{DISCUSSION}

In our case we excluded autoimmune disorders, connective tissue diseases, as well as HIV, EBV and cytomegalovirus infections. In plasma cells Castleman disease, present in our patient, the lymph nodes have hyperplastic follicles with preserved architecture. The FDS network is not expanded [9]. The characteristic feature is represented by increased interfollicular plasma cells which are usually polyclonal, but may be monotype (frequently lambda light chain) in PC-Castleman disease associated with osteosclerotic myeloma or polyneuropathy, organomegaly, endocrinopathy, monoclonal gammapathy and/or skin changes (POEMS syndrome) [10]. Castleman disease has a great variation of symptoms and signs. It may be unicentric (affects one lymph node station) or multicentric (affects more than one lymph node), as in our case. $30 \%$ of patients with multicentric disease have $\mathrm{HV}$ and 70\% PC histology [11]. Multicentric Castleman disease has many manifestations: fever, night 
sweats, severe fatigue, anorexia, weakness, weight loss. Night sweats may be the manifestation of exaggerated IL6 secretion. Anemia is explained by reduced production of hepcidin in the liver under the influence of IL6, reducing iron absorption and utilization. IL6 inhibits albumin production, causing a reduction of oncotic pressure, which together with increased vascular permeability by VEGF leads to edema, ascites, pleural effusion. Our patient presented cardiac tamponade and the pathological exam described chronic inflammatory infiltrate with xanthogranulomatous reaction. Three similar cases have been described in the literature [12-14]. These cases are the PC variant of Castleman disease. The development of effusion may be due to an inflammatory syndrome. Excess IL6 impairs dendritic cell maturation and promotes a Th2 immune profile, expansion of CD5-b lymphocytes producing autoantibodies. Our patient presented another atypical feature: the large skin lesions resembling Kaposi sarcoma, caused by infiltrates of lymphocytes and plasma cells in the dermis, a characteristic feature of the POEMS syndrome. The severe abdominal pain may be secondary to a debilitating polyneuropathy also seen in patients with POEMS syndrome. Therefore, we believe that this patient might have had a Castleman disease variant of POEMS syndrome that is not associated with clonal plasma cell disorder and should be distinguished from POEMS syndrome which diagnosis is made with the major criteria, two of which must include polyradiculopathy and monoclonal plasma cell disorder and at least one minor criteria (oragnomegaly, endocrinopathy, characteristic skin changes, papilledema, extravascular volume overload and thrombocytosis).
Overexpression of inflammatory cytokines has been incriminated in the pathogenesis of POEMS syndrome. In a case presented by Shikama $\mathrm{N}$ et al. [15] a patient with cardiac tamponade had high levels of IL6 in the pericardial fluid compared with serum levels $(1760 v s .6 .57 \mathrm{pg} / \mathrm{mL})$. There are no published randomized clinical trials for the treatment of Castleman disease. Corticosteroids are administered to manage acute exacerbation of multicentric Castleman disease. High-dose steroids improve symptoms and lymphadenopathy [16]. Most patients require excessive doses of steroids. Steroids are therefore associated with rituximab or alkylating agents. Steroid therapy is associated with an increased risk of infection and death due to sepsis. In some case reports there were described other agents with activity in plasma cells-Castleman disease including: interferon- $\alpha$, bortezomib, thalidomide, suramin (interferes with the binding of IL6 to its receptor), anakinra (an IL1-R antagonist), siltuximab (mAb anti IL6).

\section{CONCLUSION}

The clinical manifestations in our patient were atypical, such as cardiac tamponade and large skin lesions that were not Kapossi sarcoma. Castleman disease is a rare disease and it is important to make a differential diagnosis with lymphoma and serositis with an absolute necessity of a histopathological examination in order to have a diagnosis. The diagnosis in this case was made by lymph node and skin biopsy. Symptomatic, multicentric HIV negative Castleman disease responds poorly to corticosteroid treatment. New drugs will find their place in the management of Castleman disease.

\footnotetext{
Prezentăm cazul unei paciente de 76 ani internată în Clinica de Cardiologie pentru astenie fizică, transpirații profuze şi dispnee cu ortopnee cu debut de aproximativ o lună. Examenele clinice şi paraclinice au confirmat diagnosticul de tamponadă cardiacă. S-a intervenit chirurgical şi s-au evacuat $400 \mathrm{ml}$ lichid pericardic sero-citrin, limpede. Evoluția postoperatorie a fost marcată de reapariția simptomelor care au necesitat un nou drenaj pericardic după 3 săptămâni, când s-au evacuat $600 \mathrm{ml}$ lichid limpede şi s-a efectuat biopsie pericardică. Examenul histopatologic a evidențiat pericardită seroasă cu infiltrat inflamator, reacție xantogranulomatoasă şi hiperplazie mezotelială. Ulterior pacienta a fost transferată in clinica de medicină internă pentru investigații suplimentare. Examenul clinic a evidențiat pacienta cu stare generală alterată, cu tegumente palide, murmur vezicular absent bazal bilateral, prezentând hiperpigmentare cutantă la nivelul hemiabdomenului drept cu extensie pe coapsa dreptă, cu marginea indurată. La nivel latero-cervical drept şi axilar bilateral se evidențiază ganglioni de $3 \mathrm{~cm}$ mobili, neaderenți la planul superficial, precum şi blocuri adenopatice inghinal
} 
bilateral. CT torace - abdomen evidentiază pleurezie bilaterală în cantitate medie şi multiple adenopatii de ambele părți ale diafragmului. Se efectuează biopsie cutanată, aspirat medular şi biopsie ganglionară axilară dreaptă. Examenele histopatologic şi imunohistochimic au confirmat diagnosticul de boală Castleman.

Correspondence to: Ionel Copaci, Center of Internal Medicine, Fundeni Clinical Institute Şos. Fundeni 258, sector 2, Bucharest, Romania, Phone: +40722300250 , Fax: +40213119190 E-mail: ionel.copaci@gmail.com

Mariana Mihăilă, Center of Internal Medicine, Fundeni Clinical Institute Şos. Fundeni 258, sector 2, Bucharest, Romania, Phone: + 40722207281, Fax: + 40213119190 E-mail:m.mihaila@yahoo.com

\section{REFERENCES}

1. MAGRINI U, LUCIONI M, INCARDONA P, BOVERI E, PAULLI M. Castleman's disease: update. Pathologica, 2003; 95(5):227-9.

2. KELLER AR, HOCHHOLZER L, CASTLEMAN B. Hyaline-vascular and plasma-cell types of giant lymph node hyperplasia of the mediastinum and other locations. Cancer. 1972; 29:670-683.

3. BATES DO, HARPER SJ. Regulation of vascular permeability by vascular endothelial growth factors. Vascul Pharmacol 2002; 39:225-237.

4. PEH SC, SHAMINIE J, POPPEMA S, KIM LH. The immunophenotypic patterns of follicle centre and mantle zone in Castleman's disease. Singapore Med J. 2003; 44:185-191.

5. MENKE DM. Ly-1b cells and Castleman Disease. Blood. 2000; 96:1614-1616.

6. CHEN WC, JONES D, HO CL et al. Cytogenetic anomalies in hyaline vascular Castleman disease: report of two cases with reappraisal of histogenesis. Cancer Genet Cytogenet 2006; 164:110-111.

7. CRONIN DM, WARNKE RD. Castleman disease: an update on classification and the spectrum of associated lesions. Adv Anat Pathol 2009; 16:236-246.

8. LEE J, BAN JY, WON KY, et al. Expression of EGFR and folicullar dendritic markers in lymphoid follicles from patients with Castleman's disease. Oncol Rep 2008; 20:851-856.

9. NGUYEN DT, DIAMOND LW, HANSMANN ML, et al. Castleman's disease. Differences in follicular dendritic network in the hyaline vascular and plasma cell variants. Histopathology 1994; 24:437-443.

10. HALL PA, DONAGHY M, COTTER FE, STANSFELD AG, LEVISON DA. An immunohistological and genotypic study of the plasma cell form of Castleman's disease. Histopathology 1989; 14:333-346.

11. WEISENBURGER DD, NATHWANI BN, WINBERG CD, RAPPAPORT H. Multicentric angiofollicular lymph node hyperplasia: a clinicopathologic study of 16 cases. Hum. Pathol. 1985; 16:162-172.

12. NICOLOSI AC, ALMASSI GH, KOMOROWSKI R. Cardiac tamponade secondary to giant lymph node hyperplasia (Castleman's disease). Chest 1994; 105(2):637-639.

13. SHAHIDI H, KVALE PA. Cardiac tamponade secondary to giant lymph node hyperplasia. Chest 1995; $107(2): 581$.

14. ZHANG C, MIAO Q, CHEN G, LIU X, MA G, CAO L, DENG H. Pericardial tamponade secondary to Castleman's disease. Ann Thorac Surg. 2009; 88(6):2039.

15. SHIKAMA N, ISONO A, OTSUKA Y, TERANO T, HIRAI A. A case of POEMS syndrome with high concentrations of interleukin 6 in pericardial fluid. J Intern Med. 2001; 250(2):170.

16. BOWNE WB, LEWIS JJ, FILIPPA DA, et al. The management of unicentric and multicentric Castleman disease; a report of 16 cases and a review of the literature. Cancer. 1999; 85:706-717.

Received July 30, 2015 